\title{
Angioedema and Urticaria Associated with Fluoxetine in a Preadolescent Boy
}

\author{
Preadolesan Bir Erkek Çocukta Fluoksetinle Illişkili Anjiyoödem ve Ürtiker
}

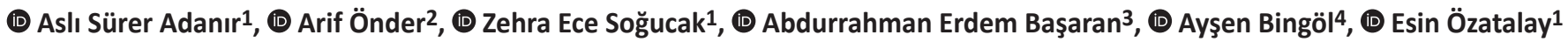 \\ ${ }^{1}$ Akdeniz University Faculty of Medicine, Department of Child and Adolescent Psychiatry, Antalya, Turkey \\ ${ }^{2}$ Manisa Psychiatry Hospital, Clinic of Child and Adolescent Psychiatry, Manisa, Turkey \\ ${ }^{3}$ Akdeniz University Faculty of Medicine, Department of Pediatrics, Antalya, Turkey \\ ${ }^{4}$ Akdeniz University Faculty of Medicine, Department of Pediatric Allergy-Immunology, Antalya, Turkey
}

\section{Abstract}

Angioedema is defined as increased permeability and dilatation of the capillaries in the deep dermis or subcutaneous or submucosal tissues leading to localized swelling, often affecting the upper respiratory and gastrointestinal tracts. It can also be observed as a rare adverse effect of selective serotonin reuptake inhibitors, as is the case with many other drugs. Here, we report a 10-year-old boy who had urticaria with fluoxetine use, showed recovery after cessation of the drug, and manifested with urticaria and angioedema after re-prescription. In the literature, there are two previous case reports of angioedema with fluoxetine. One case of angioedema accompanied by urticaria and showed a flu-like presentation 2 days after ingestion of high-dose fluoxetine. The other case, reporting angioedema with $10 \mathrm{mg} /$ day, was without urticaria and thought to be a pseudoallergic reaction. We assume that our case is unique in this respect for that angioedema developed with therapeutic doses and thought to be allergic.

Keywords: Adverse effect, angioedema, child, fluoxetine, urticaria

\section{Öz}

Anjiyoödem, derin dermis veya deri altı dokulardaki kılcal damarların artmış geçirgenliği ve dilatasyonu ile seyreden ve sıklıkla üst solunum ve gastrointestinal sistemleri etkileyen lokal ödem olarak tanımlanır. Diğer birçok ilaç gibi, seçici serotonin geri alım inhibitörlerinin nadir bir yan etki olarak da görülebilir. Burada fluoksetin ile ürtikeri ortaya çıkan ve ilacın kesilmesinden sonra düzelen, ilacın tekrar başlanması ile ürtiker ve anjiyoödemi ortaya çıkan 10 yaşında bir erkek çocuğu sunuyoruz. Literatürde, fluoksetin ile ortaya çıkan 2 anjiyoödem olgusu daha bulunmaktadır. Birisi yüksek doz fluoksetin alımından 2 gün sonra grip benzeri bir klinik görünümle seyreden ve ürtiker ve anjiyoödemin eşlik ettiği olgu, diğeri ise $10 \mathrm{mg} / g u ̈ n$ fluoksetin ile anjiyoödem bildiren, ancak ürtiker görülmemesi nedeniyle psödoalerjik olduğu düşünülen olgudur. Bu açıdan bizim olgumuzun benzersiz olduğunu düşünüyoruz, çünkü anjiyoödem terapötik dozlarda gelişmiş ancak allerjik kökenli olarak değerlendirilmiştir.

Anahtar Kelimeler: Anjiyoödem, çocuk, fluoksetin, ürtiker, yan etki

\section{Introduction}

Angioedema is defined as increased permeability and dilatation of the capillaries in the deep dermis or subcutaneous or submucosal tissues leading to localized swelling, often affecting the upper respiratory and gastrointestinal tracts. Increased vascular permeability may be mast cell (such as histamine)-mediated, bradykinin-mediated; or of unknown origin. Mast cell mediators are usually associated with urticaria and itch, whereas bradykinin has no association. Urticaria is defined as the vascular reaction of the upper dermis marked by itching and the transient appearance of raised patches that are redder or paler than the surrounding skin. ${ }^{1}$

Angiotensin-converting enzyme inhibitors (ACEls), non-steroid anti-inflammatory drugs (NSAID), neuromuscular blockers and penicillin are the most common medications held responsible for angioedema, ${ }^{2}$ but it can also be observed as a rare but potentially life-threatening adverse effect of selective serotonin reuptake inhibitors (SSRIs). There are 4 reported cases of angioedema associated with SSRIs in the literature. ${ }^{3-6}$ Here, we report a 10-year-old boy who had urticaria associated with

Address for Correspondence/Yazışma Adresi: Aslı Sürer Adanır MD, Akdeniz University Faculty of Medicine, Department of Child and Adolescent Psychiatry, Antalya, Turkey

Phone: +90 2422496797 E-mail: asliadanir@hotmail.com ORCID ID: orcid.org/0000-0002-6223-756X

Received/Geliș Tarihi: 11.12.2017 Accepted/Kabul Tarihi: 23.01.2018

${ }^{\circ}$ Copyright 2018 by Society of Pediatric Emergency and Intensive Care Medicine

Journal of Pediatric Emergency and Pediatric Intensive Care published by Galenos Yayınevi. 
fluoxetine use, showed recovery after the cessation of the drug, and manifested with urticaria and angioedema after the re-prescription.

\section{Case}

A 10-year-old boy presented to our pediatric emergency unit with diffuse itchy skin lesions (Figure 1) and swollen lips and tongue (Figure 2). His parents reported that he was on fluoxetine $10 \mathrm{mg}$ treatment for 12 days for his anxiety symptoms, and he had mild urticarial lesions for 2 days. Within a few hours, the lesions had spread to all of his body and he started to have difficulty in talking and breathing because of swollen lips and tongue. Examinations and questioning of the patient and information obtained from the parents ruled out food or pollen allergy, insect bites, physical exercise, NSAID use or any other etiological agents. The parents did not report any novel stressors or infection symptoms prior to the onset of angioedema. He did not take any food supplements or medication except for fluoxetine. Hereditary angioedema (HAE) was ruled out by a negative family history and normal C4 and C1 inhibitor levels.

Upon questioning and medical reports, it was learned that he was brought to the emergency department once more with diffuse urticaria two and a half years ago, while he had been taking fluoxetine $10 \mathrm{mg}$ for fifteen days. Three days before presenting to the emergency department, the family had taken him to their primary care physician, and oral pheniramine had been prescribed, but he did not benefit from the treatment. His lesions had been attributed to fluoxetine

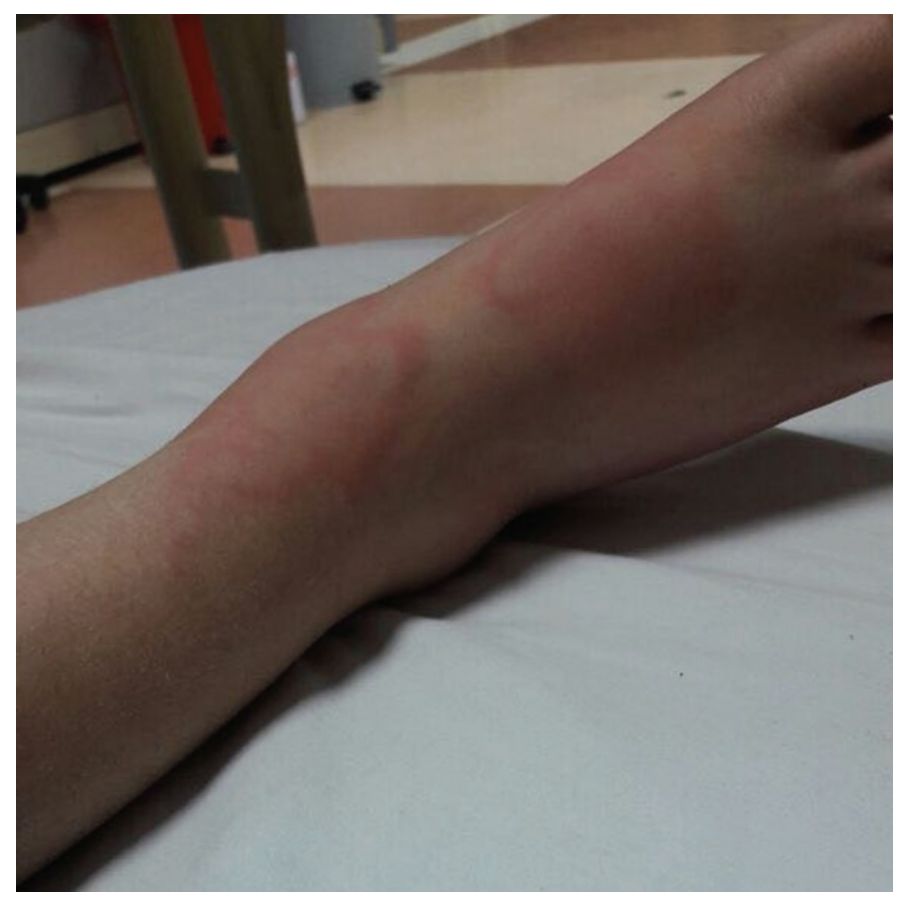

Figure 1. Urticarial lesions on the front of the leg and foot treatment and prednisolone and pheniramine were started, and cessation of fluoxetine was recommended. The lesions healed up in 2 days after then.

His lesions were attributed to fluoxetine treatment once more and intravenous prednisolone and pheniramine were given and fluoxetine was stopped. Angioedema regressed quickly after medication and complete recovery of the lesions was observed within 2 days. The patient is on sertraline treatment without any side effects now.

The patient's mother provided written informed consent for publication of this case report and accompanying images.

\section{Discussion}

Fluoxetine is usually a well-tolerated drug in children and adolescents. The most frequent adverse events are sleep problems, gastrointestinal symptoms and headache. Urticaria, skin eruptions and rarely angioedema are also reported by the manufacturer. ${ }^{7}$ There are also 4 case reports of angioedema associated with SSRIs in the literature..$^{3-6}$

There are three main forms of angioedema: extrinsic factorinduced angioedema, angioedema with C1-INH deficiency and idiopathic. The first form includes angioedema associated with allergic and non-allergic reactions due to various antigens, such as drugs, pathogens, foods, animals, venom, latex, etc. The second form is associated with C1$\mathrm{INH}$ deficiency and divided into two subtypes, as HAE and acquired angioedema. The causes of the last form, idiopathic angioedema, are unknown. Drug-induced angioedema

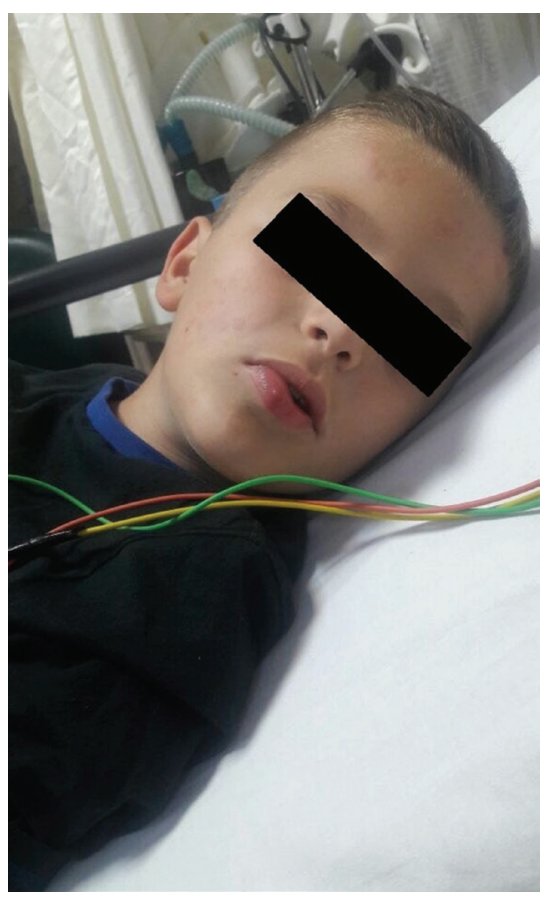

Figure 2. Swollen lips, indicating angioedema 
is classified in the extrinsic factor-induced angioedema and divided into three main categories depending on the mechanism. The first group is IgE-mediated immediate hypersensitivity reactions, especially associated with iodinated contrast media, beta-lactam antibiotics, neuromuscular blocking agents, quinolones and pyrazolones. The second includes the adverse effects of NSAIDs due to inhibition of cyclooxygenase resulting in major alterations in arachidonic acid metabolism and is generally non-allergic. Thirdly, ACEIinduced angioedema, a reaction, in which the inhibition of the degradation of bradykinin is observed, resulting in angioedema, but not urticaria. To differentiate a kinindependent angioedema, from the IgE-mediated one and NSAID intolerance, it is useful to determine as if angioedema is accompanied by urticaria or not. ${ }^{8}$

Here, we report a case of angioedema in a preadolescent, thought to be associated with fluoxetine. The temporal correlation of the occurrence of urticaria with the use of fluoxetine in the absence of comorbid illness or concurrent medications followed by its disappearance with discontinuation and re-occurrence (this time with angioedema) with the repeated use of it strongly suggested that the case was associated with fluoxetine. An evaluation with the Naranjo algorithm revealed a score of 8 , denoting a probable adverse effect. ${ }^{9}$ Due to the lack of patient and family history for similar reactions and normal C4 and C1 inhibitor levels, the diagnosis of HAE was excluded. We considered it to be an allergic reaction, as it was accompanied by urticaria. We think that he did not have angioedema at the first time he had used fluoxetine because of oral pheniramine he used for three days.

Fluoxetine is rarely associated with hypersensitivity reactions. In one case, it was reported to be related with a severe systemic hypersensitivity reaction including drug rash, eosinophilia, and systemic symptoms in a 4-year-old girl. ${ }^{10}$ There is only one other case of angioedema accompanying urticaria and flu-like symptoms developing 2 days after ingestion of high dose fluoxetine. ${ }^{5}$ The other case of angioedema attributed to treatment fluoxetine with $10 \mathrm{mg} /$ day was without urticaria and thought to be a pseudoallergic reaction. ${ }^{6}$ Our case is unique in this respect for that angioedema developed with therapeutic doses and thought to be an allergic reaction.

Regardless of the cause, clinicians should be aware of such rare but potentially life-threatening adverse effects of
SSRIs and monitor patients closely. Parent education is also imperative.

\section{Ethics}

Ethics Committee Approval: None, as it is a case report. Informed Consent: The parents of patient signed written informed consent form.

Peer-review: Externally peer-reviewed.

\section{Authorship Contributions}

Concept: Z.E.S., A.S.A., A.Ö., Design: A.S.A., Data Collection or Processing: Z.E.S., A.E.B., Analysis or Interpretation: E.Ö., A.B., A.S.A., A.Ö., Literature Search: Z.E.S., A.E.B., Writing: A.S.A., A.E.B.

Conflict of Interest: No conflict of interest was declared by the authors.

Financial Disclosure: The authors declared that this study received no financial support.

\section{References}

1. Fitzharris $\mathrm{P}$, Jordan A. Investigating recurrent angio-oedema. BMJ. 2011;343:d6607.

2. Agostoni A, Cicardi M. Drug-induced angioedema without urticaria. Drug Saf. 2001;24:599-606.

3. Mithani H, Hurwitz TA. Paroxetine-induced angioedema and tongue swelling. J Clin Psychiatry. 1996;57:486.

4. Adson DE, Erickson-Birkedahl S, Kotlyar M. An unusual presentation of sertraline and trazodone overdose. Ann Pharmacother 2001;35:1375-7.

5. Kim SW, Pentel PR. Flu-like symptoms associated with fluoxetine overdose: A case report. J Toxicol Clin Toxicol. 1989;27:389-393.

6. Tuman TC, Demir N, Topal Z, Tuman BA, Tufan EA. Angioedema probably related to fluoxetine in a preadolescent being followed up for major depressive disorder. J Child Adolesc Psychopharmacol. 2013;23:697-8.

7. Prozac, manufacturer's insert.

8. Inomata N. Recent advances in drug-induced angioedema. Allergol Int. 2012;61:545-57.

9. Naranjo CA, Busto U, Sellers EM, Sandor P, Ruiz I, et al. A method for estimating the probability of adverse drug reactions. Clin Pharmacol Ther. 1981;30:239-45.

10. Vignesh P, Kishore J, Kumar A, Vinay K, Dogra S, et al. A Young Child with Eosinophilia, Rash, and Multisystem Illness: Drug Rash, Eosinophilia, and Systemic Symptoms Syndrome After Receipt of Fluoxetine. Pediatr Dermatol. 2017;34:120-5. 